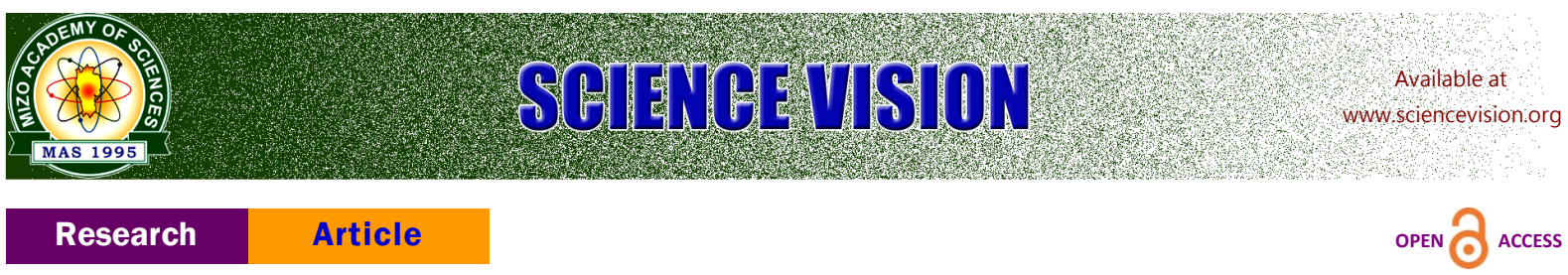

\title{
A systematic list of mammals of Mizoram, India
}

\author{
H. Lalthanzara \\ Department of Zoology, Pachhunga University College, Aizawl 796oor, Mizoram, India
}

\begin{abstract}
A comprehensive systematic list of wild mammals of the state of Mizoram, northeast India, has been collated from historical records, primary and secondary information by incorporating reliable data after personal interview with elderly prominent hunters. A total of 126 species of wild mammals belonging to 32 families under 11 orders, including 8 primate species, 14 herbivores with angulates, among carnivores - 3 ursids, 2 canids, 8 felids, 19 lesser carnivores; and 5 fossoreal, 9 arboreal, 22 rodents, 35 chiropterans and 1 aquatic mammal are listed. Bats (Chiroptera) formed the largest group (28\%) with 35 species under 7 families followed by carnivores (25\%) with 32 species and rodents (24\%) with 30 species. Furthermore, Cetacea, Proboscidae, Scandentia and Pholidota orders were represented by a single species each. The rats and mice family Muridae formed the biggest family with 16 species followed by the vesper bats family Vespertilionidae with 14 species. The list contains three critically endangered species including two locally extinct species, eight endangered species including two locally extinct species, 18 vulnerable species including one locally extinct species and 8 near-threatened species, i.e. a total of 37 threatened species. The list also provides the vernacular name, common English name and scientific name of each species, local status, IUCN (2016-3) threatened category, WPA schedule and CITES appendix were given. Five species were considered as locally extinct; habitat destruction and poaching being the major cause, and therefore, immediate conservative measures are suggested.
\end{abstract}

Key words: Mammals; Mizoram; species; diversity; wildlife; Indo-Myanmar.

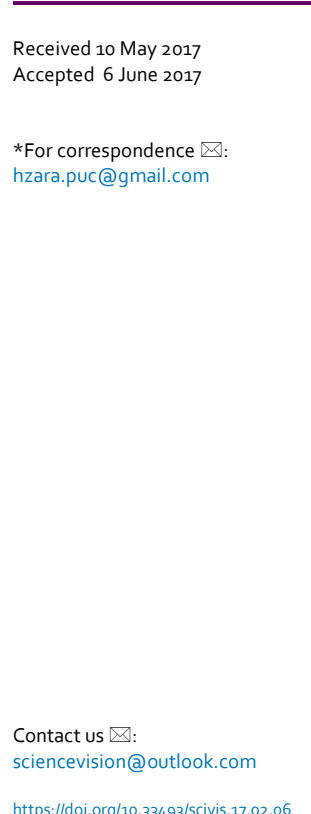

https://doi.org/10.33493/scivis.17.02.06

\section{Introduction}

Mammals are groups of vertebrates characterised by worm-blood, hairs, four-chambered heart, single jaw bone and sweat glands. Female nourished their babies with milk from their mammary glands. The smallest mammal is the hog-nosed bat (bumblebee bat, Craseonycteris thonglongyai), which weighs about $2.0 \mathrm{~g}$ and the largest is the blue whale (Balaenoptera musculus), which measures about 100 feet long and weigh about $140,000 \mathrm{~kg}$. According to Wilson and
Reeder, there are 1,229 genera 5,416 species of living mammals in the world. ${ }^{1}$ Out of these, a total of 423 species (i.e. $7.81 \%$ of the global mammalian species), belonging to 48 families and 14 orders have been reported from India by Sharma et al. ${ }^{2}$ Meanwhile, Menon ${ }^{3}$ reported about 400 species of mammals and Zoo's Print ${ }^{4}$ has listed 417 species of Indian mammals under 48 families. The eastern neighbouring country Myanmar has a record of 257 mammal species. ${ }^{5}$ The other neighbouring country in the west, Bangladesh recorded 138 mammals including 127 living and 
11 extinct species. ${ }^{6}$ Kerala state of India recorded 118 species of mammals, 15 of which are endemic to Western Ghats, and 29 species fall under the various threatened categories of IUCN?

Northeast India is the transitional zone between the India, Indo-Malayan and IndoChinese biogeographic regions and represents the physical corridor for some of India's flora and fauna. Out of India's three biodiversity hotspots, northeast India falls within two worlds most diversity riches sites, i.e. the eastern Himalaya biodiversity hotspots and the IndoMyanmar biodiversity hotspots. Being within the two biodiversity hotspots region, its high endemic species and a large number of rare and endangered species are of highly valued. Choudhury ${ }^{8}$ reported that Assam has a rich mammalian diversity comprising 193 species of mammals belonging to 32 families, thus housing about $60 \%$ of the country's mammalian diversity. Meghalaya is known to harbours 139 species of mammals under 83 genera that belongs to 27 families. ${ }^{9}$ Manipur has a list of 31 mammals. ${ }^{10}$ Tripura is a home for around 90 species of mammals under 65 genera and 10 orders. ${ }^{11}$ Nagaland has a record of at least 106 species of mammals, including 9 insectivores, 34 bats, 7 primates, 1 pan-golin, 34 carnivores, 1 elephant, 7 ungulates, 1 hare and at least 12 rodents. ${ }^{12} \mathrm{~A}$ total of 105 species of mammals has been recorded from Arunachal Pradesh by De et al..$^{13}$. These information definitely indicate the richness of mammalian species in northeast India.

In regard to Mizoram, there is no comprehensive record of mammalian diversity in the state. The previous records includes the pioneering work of Sawmliana, ${ }^{14}$ a few record of the Mizo Envis, ${ }^{15}$ Zonunmawia and Pradhan, ${ }^{16}$ Lalmuansanga, ${ }^{17}$ works on rodents by Mandal et al., ${ }^{18,19}$ Zirliana, ${ }^{20}$ works on bats (chiroptera) by Mandal et al., ${ }^{21}$ and Vanlalnghaka, ${ }^{22-23}$ and mammals by Mandal et al. ${ }^{24}$; the reproductive biological study of Macaca arctiodes by Zothansiama and Solanki. ${ }^{25}$ It is noteworthy to mention that Sawmliana ${ }^{14}$ listed 98 mammal species updating the state forest department records of 54 species. Mandal et al. ${ }^{24}$ listed 84 species of mammals from Mizoram including 8 primates, 8 cats, 12 carnivores, 2 canids, 2 ursids, 7 herbivores with angulates, 6 fossoreal and 8 arboreals. It was generally believed and observed that due to certain anthropogenic activities like habitat destruction, poaching and infrastructural developments, some of the mammalian species starts dwindling from the state. In view of the above information, it was felt necessary that a comprehensive list of mammals have to be compiled from exiting literatures, historical records and interview with hunters and prominent citizens. Thus keeping the urgent need in mind, the present article has come up to motivate researchers and mammalogist.

\section{Methodology}

Mizoram (area 21,087 sq. km., location $21^{\circ}$ $58^{\prime} \mathrm{N}$ to $24^{\circ} 35^{\prime} \mathrm{N}$ latitude and $92^{\circ} 15$ to $93^{\circ} 29^{\prime} \mathrm{E}$ longitude) is located in north-east India. It has a state boundary in the north with Manipur, Assam and Tripura and an international boundary with Bangladesh in the west and south (318 $\mathrm{kms}$ ) and Myanmar in the east and south (404 $\mathrm{kms}$ ) (Figure 1). It lies within the Indo-Myanmar Biodiversity Hotspot area. Mizoram is rich in wild flora and fauna, both in variety and abundance. The dense natural forest covers 3,158.57 sq. $\mathrm{km}$. (i.e. $14.98 \%$ of the total area), and is divided into tropical wet evergreen, tropical semievergreen and montane subtropical pine forests with an annual rainfall of about $2,500 \mathrm{~mm} .{ }^{26}$ The medium dense forest accounts for 2,628.08 sq. $\mathrm{km}$. and the bamboo forest accounts for a further $6,707.37 \mathrm{sq}$. km. Thick canopy forest with dense undergrowth and the high altitude, rugged and steep landscape covered by forest are home for many important threatened animals as well as ornamental plants.

In addition to personal experience, information was collated mainly from literatures and by interview with local hunters, prominent citizens from different parts of the state and through intensive field survey within the state during 2010-2016. Local status of each species was proposed after seven years of survey. Diversity of bats was confirmed and finalised by $C$. 


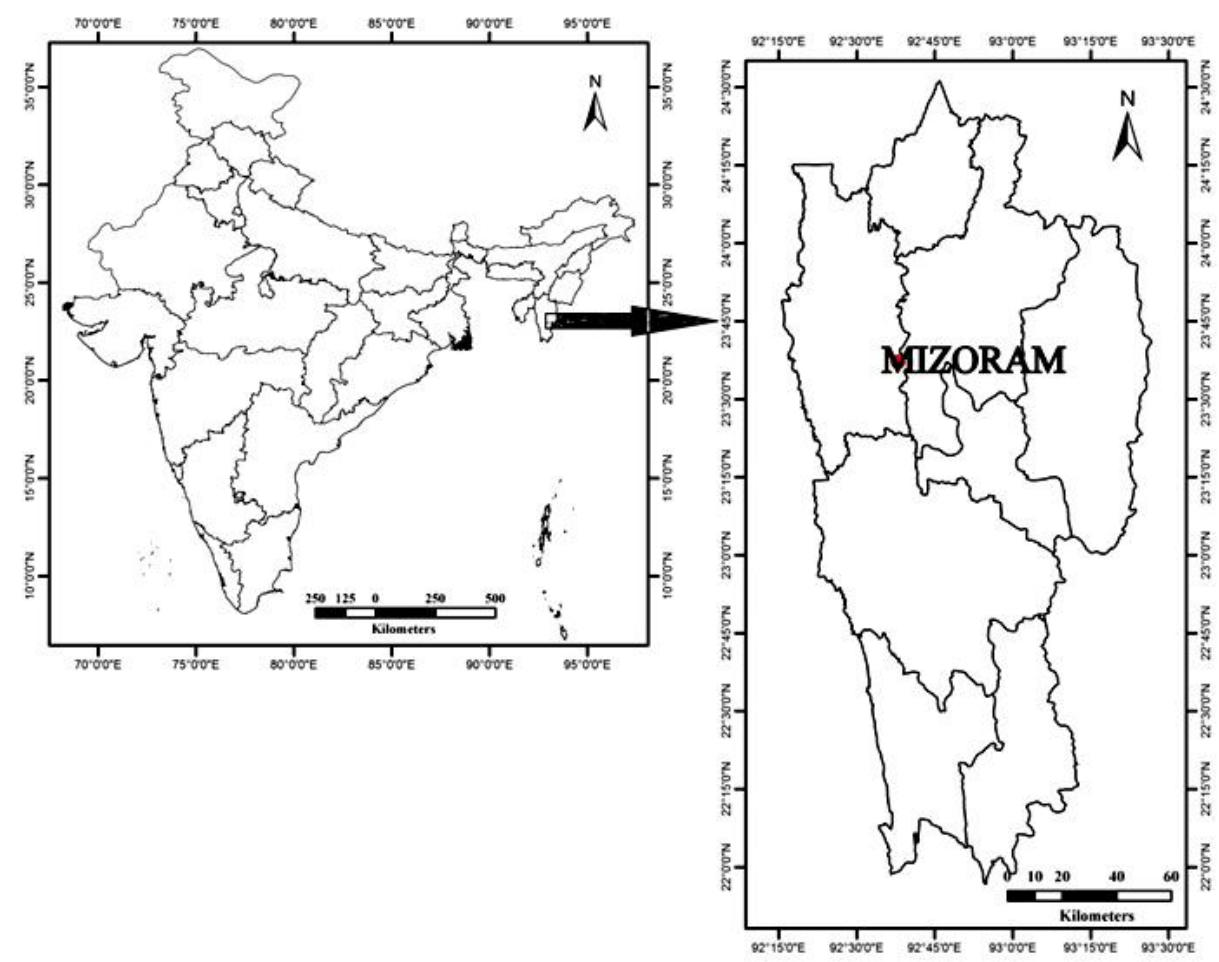

Figure 1 | Map of India, showing location of study site (Mizoram).

Vanlalnghaka, Chiropterologist, Department of Zoology, Government Serchhip College, Mizoram. M. Sawmliana, retired Forest Officer and author of the Book of Mizoram Plants has contributed a large amount of information. Nomenclatures were mainly based on IUCN Red List ${ }^{27}$ and Wilson and Reeder ${ }^{1}$ and the publication of Zoos' Print Checklist of Indian mammals, Revised and updated ${ }^{2}$ was followed in taxonomy. The threatened category of each species was given based on IUCN Red List of threatened Species 2016-3.27 IWPA schedule ${ }^{28}$ and CITES appendi$\operatorname{ces}^{29}$ were given based on latest versions.

\section{Results and Discussion}

A total of 126 species of wild mammals belonging to 32 families under 11 orders have been listed (Table 1). The list includes one proboscidea (elephant), one scandentia (treeshrew), eight primates (i.e. 6\%), 30 rodentia (rodents) i.e.
$24 \%, 35$ chiroptera (bats) i.e. $28 \%$, one pholidota (Pangolin), 32 carnivora (carnivores) 25\%, three perissodactyla (rhinoceros), 10 artiodactyla (herbivores with angulates) i.e. $8 \%$ and one cetacean (dolphin, the only aquatic mammal record of the state) (Figure 2).

Mizoram harbours as many as eight species of primates, while the whole country of India housed 15 species. All the species, with the exception of Rhesus Macaque, are endemic to the northeast region and are under threatened category. ${ }^{27}$ Two species, viz. Phayre's leaf-monkey (Trachypithecus phayrei) and hoolock gibbon (Hylobates hoolock) are endangered category of IUCN red list, slow loris (Nycticebus bengalensis), pig-tailed macaque (Macaca leonina), stumptailed macaque ( $M$. arctoides) and capped langur (T. pileatus) are under vulnerable category. Assamese macaque ( $M$. assamensis) belongs to nearThreatened category. Four species are under WPA schedule I and three species are catego- 
Sci Vis 17 (2), 104-121 (2017)

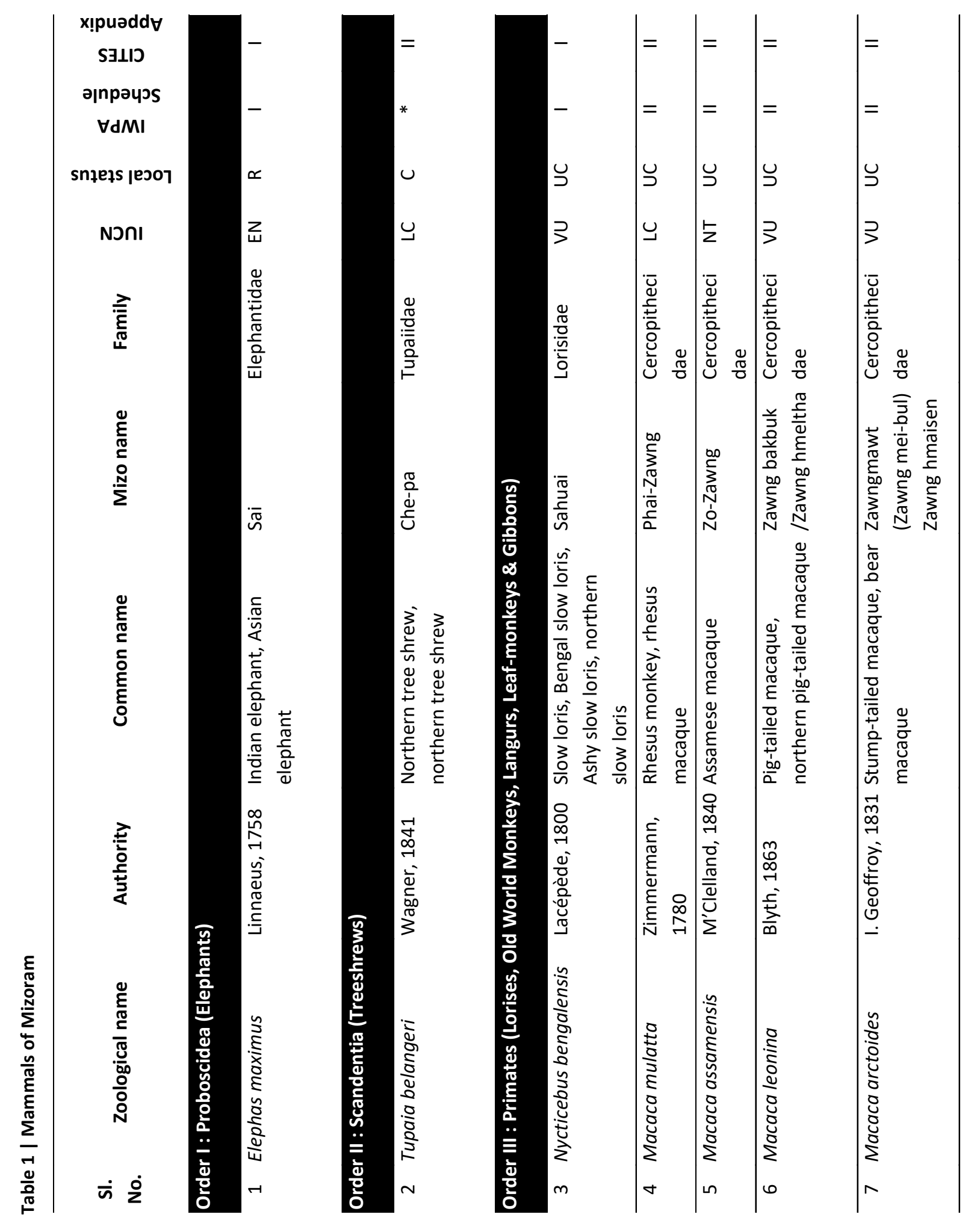




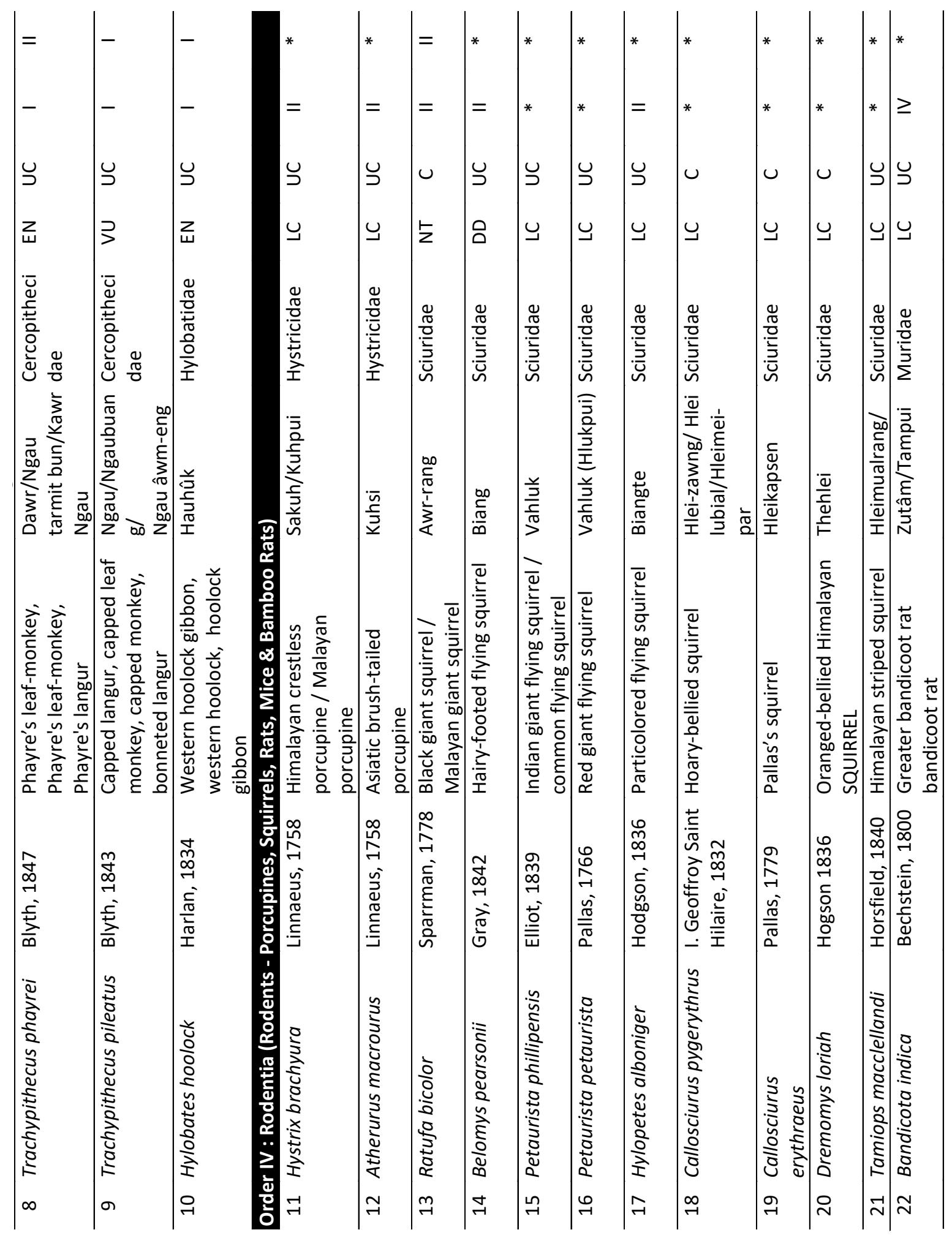




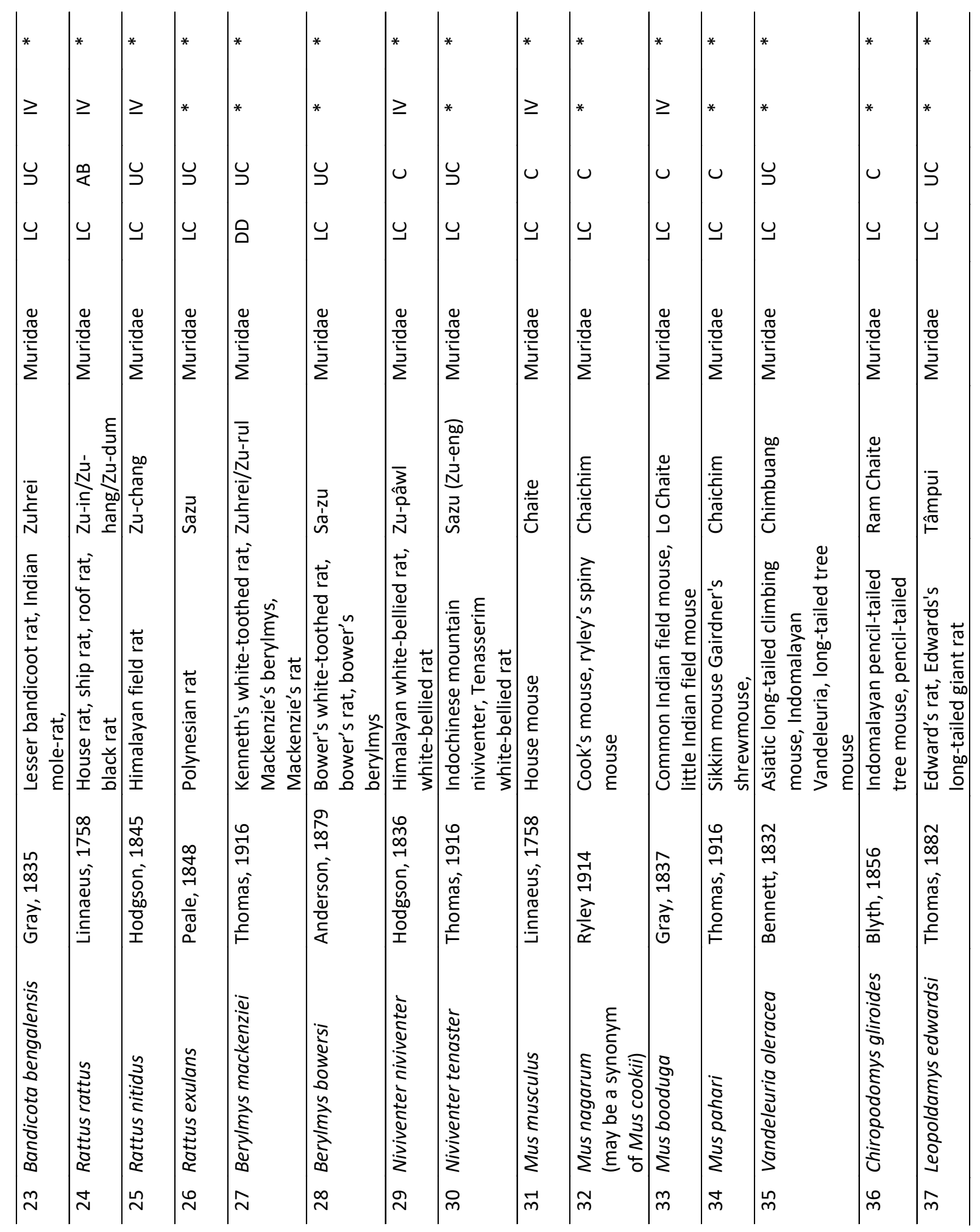




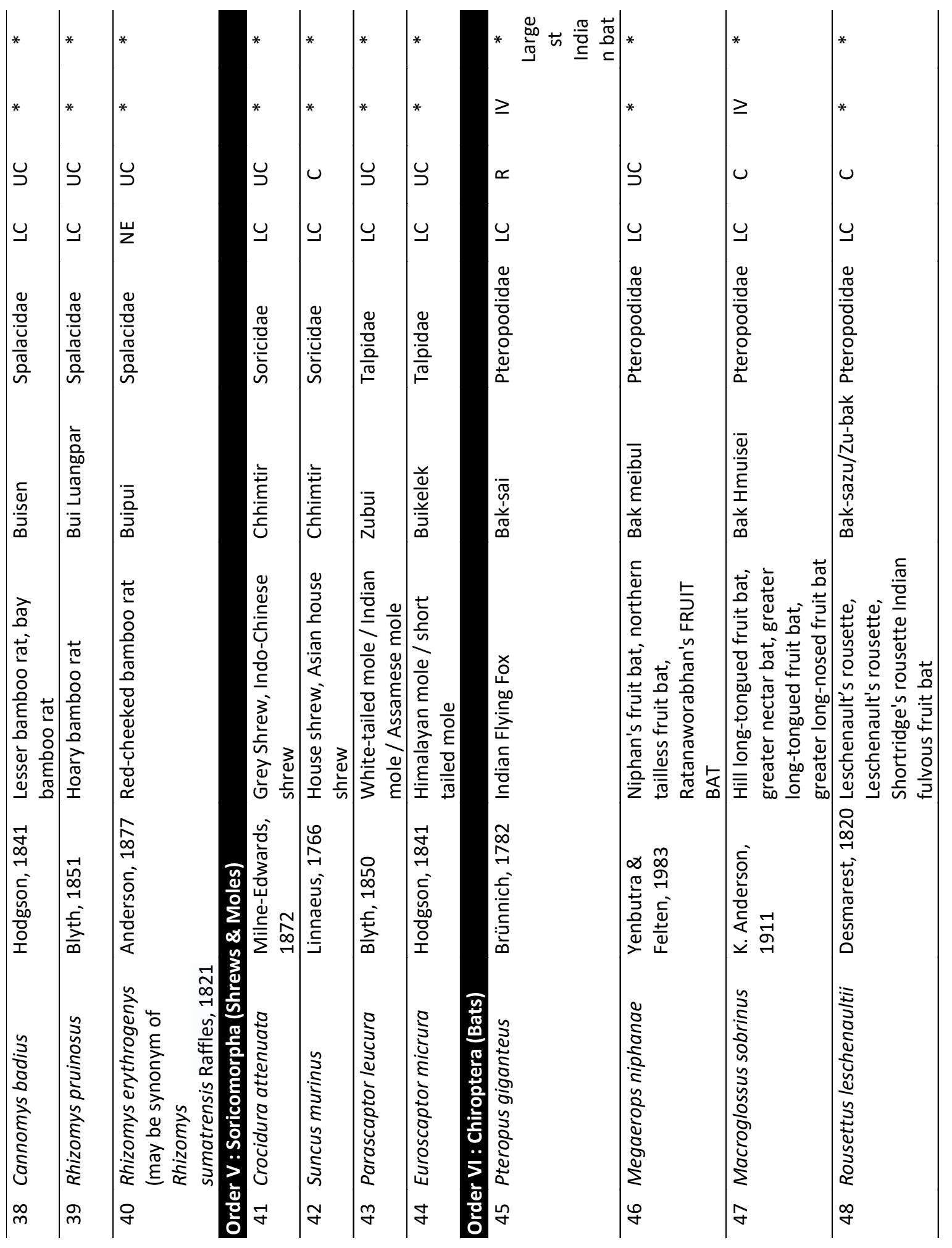




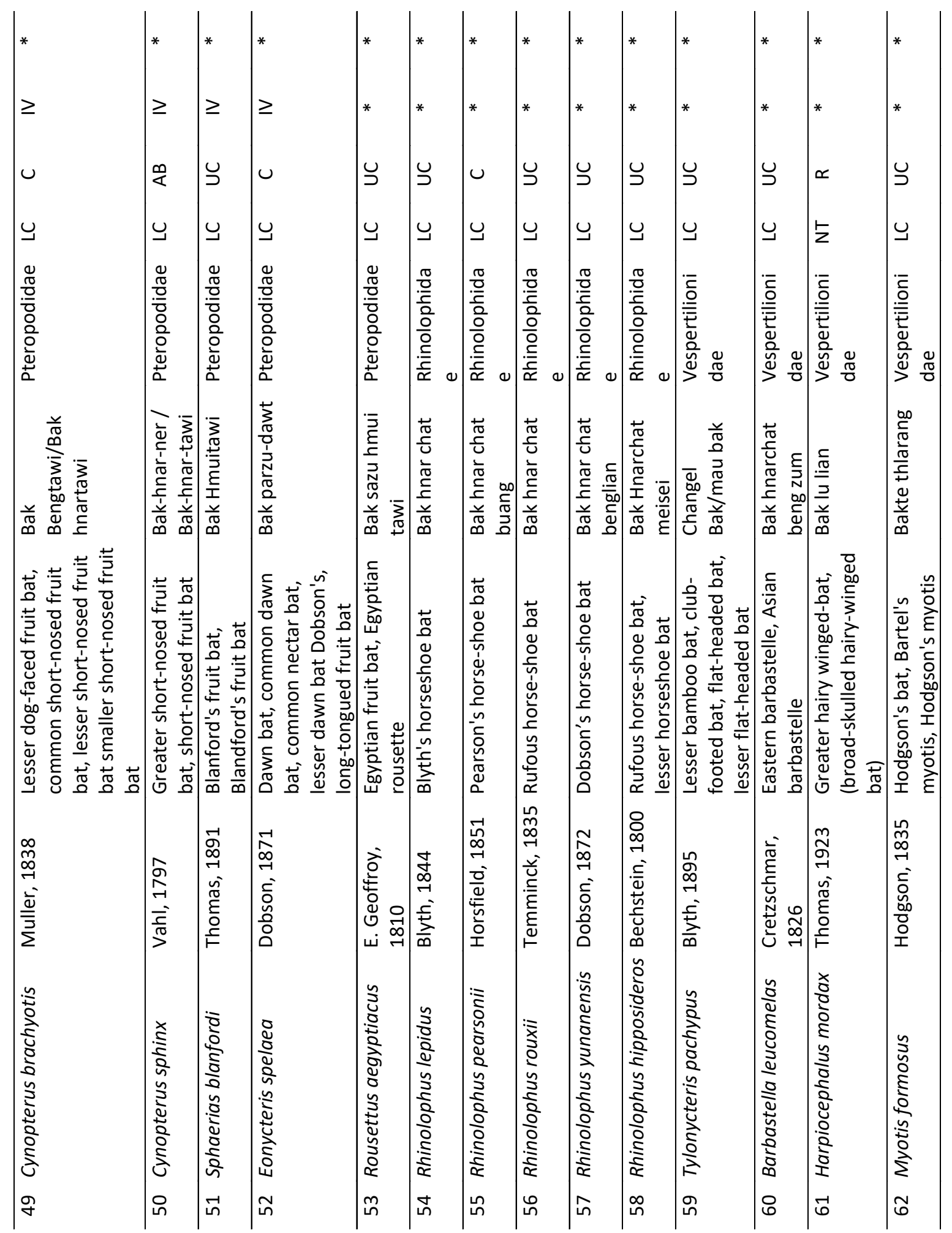




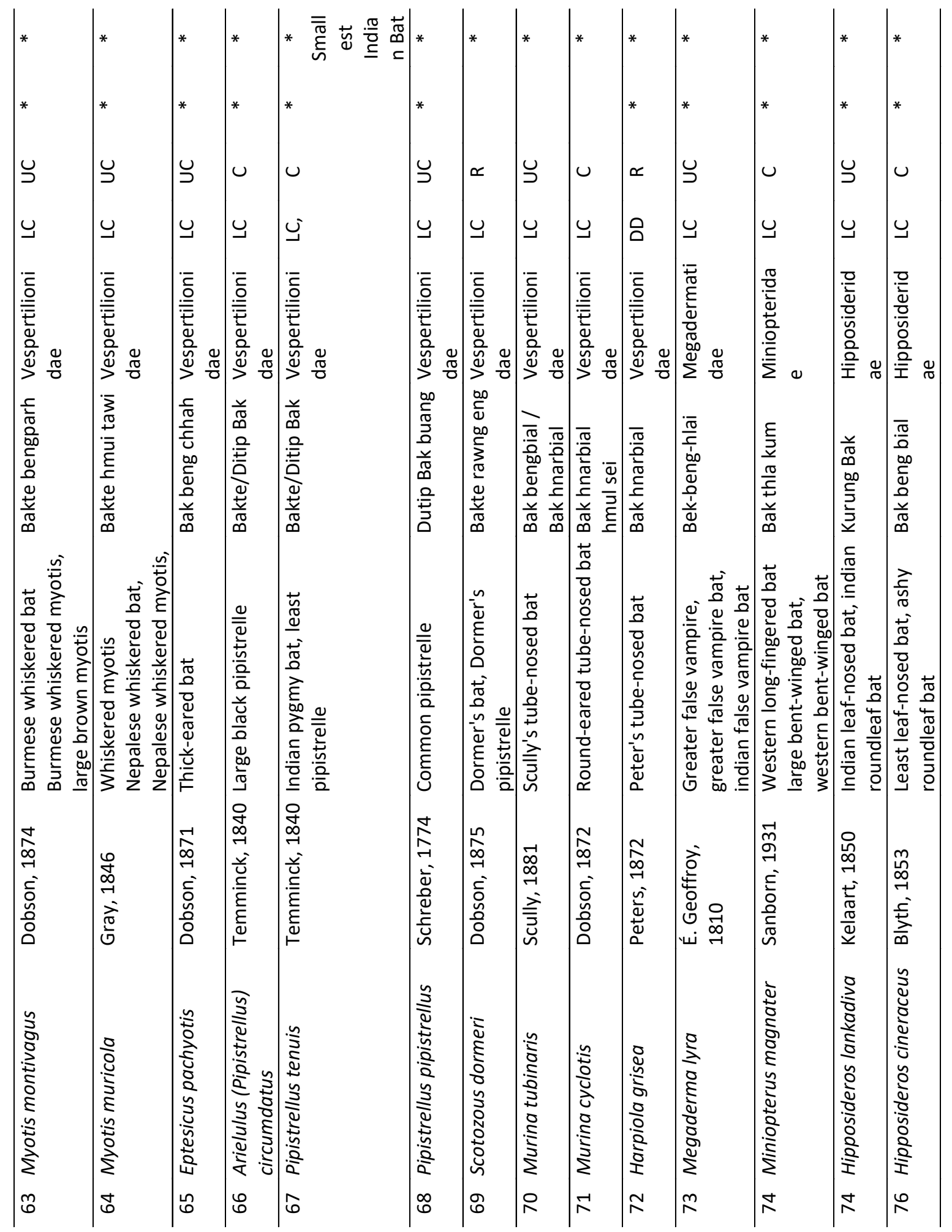




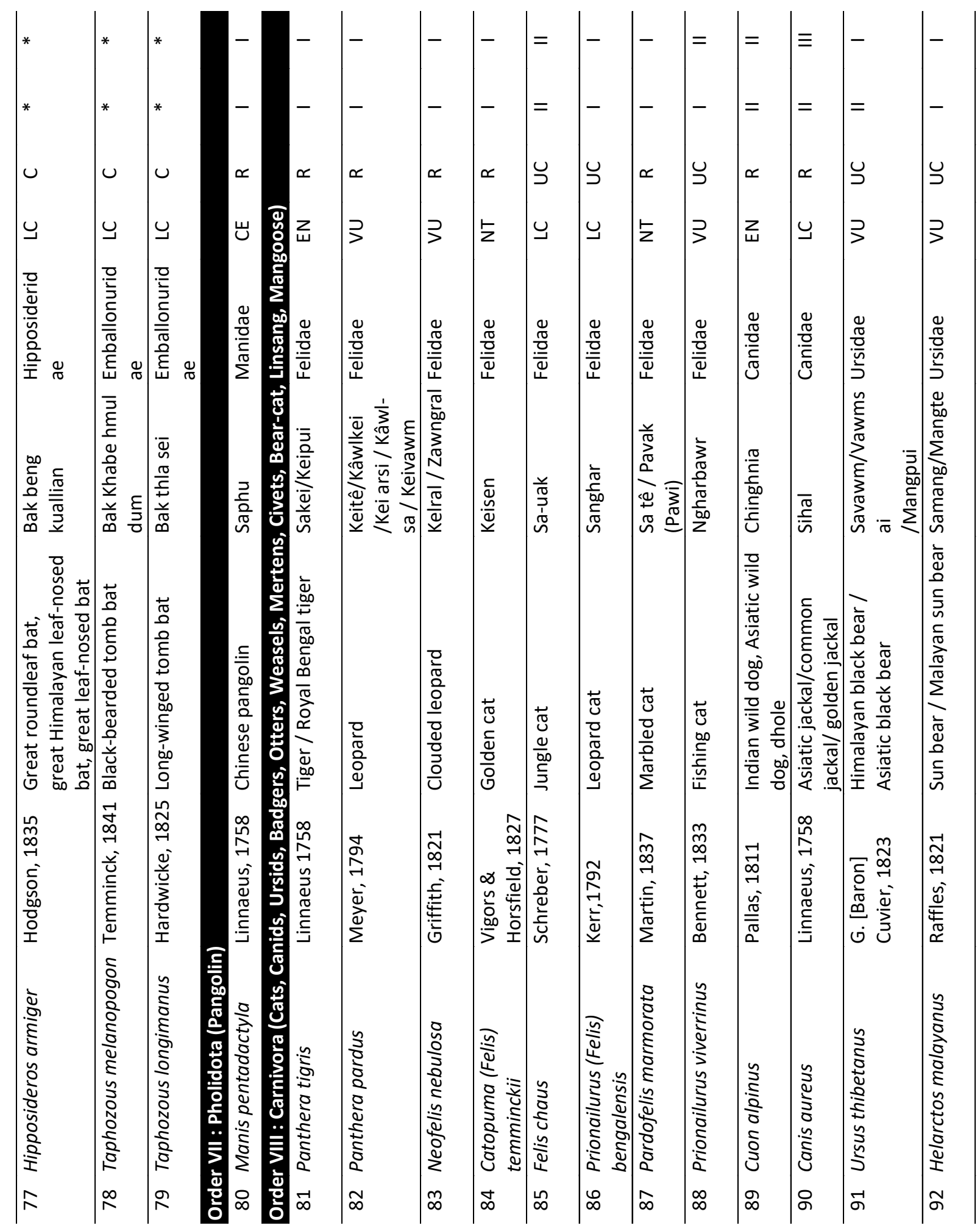




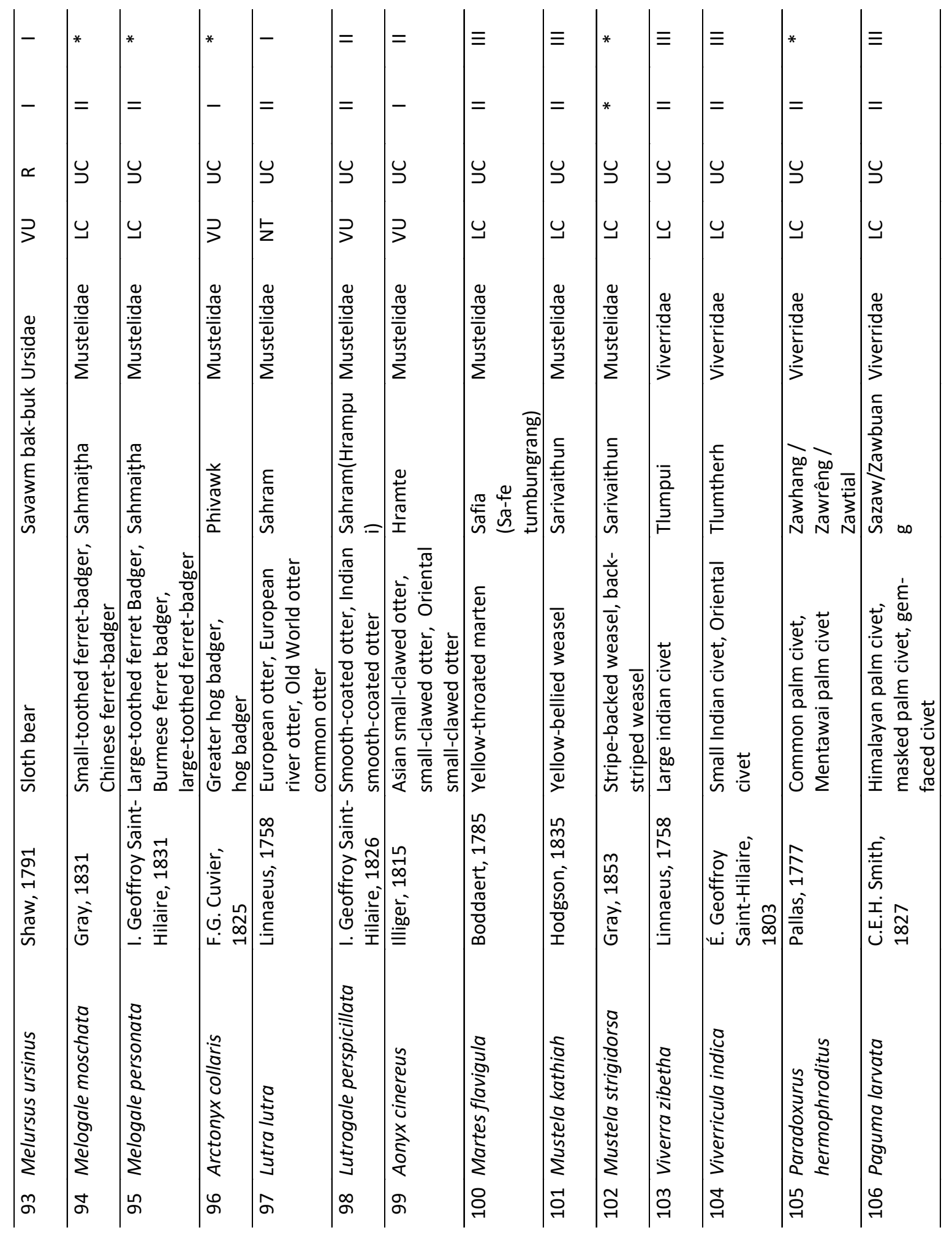




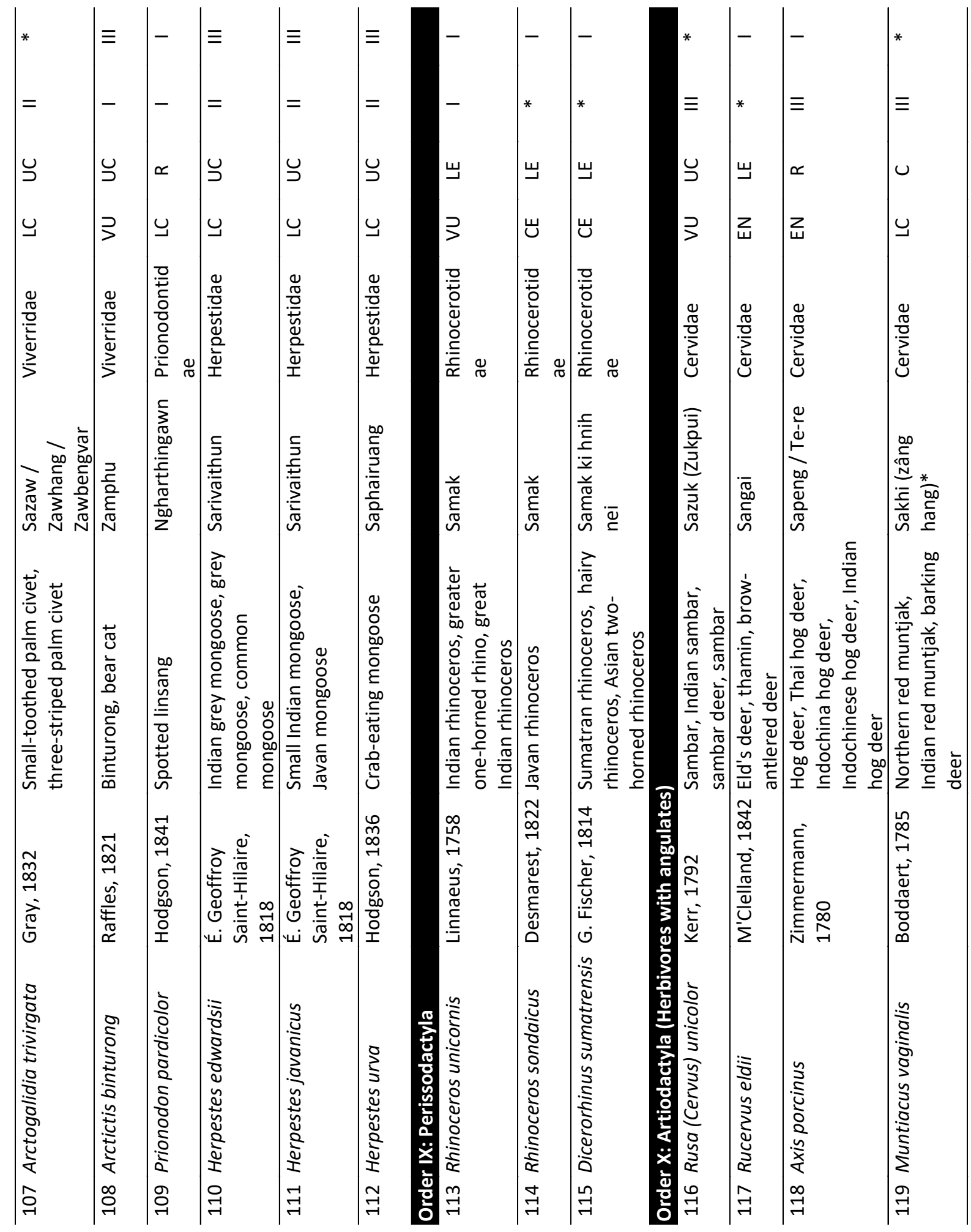


Sci Vis 17 (2), 104-121 (2017)

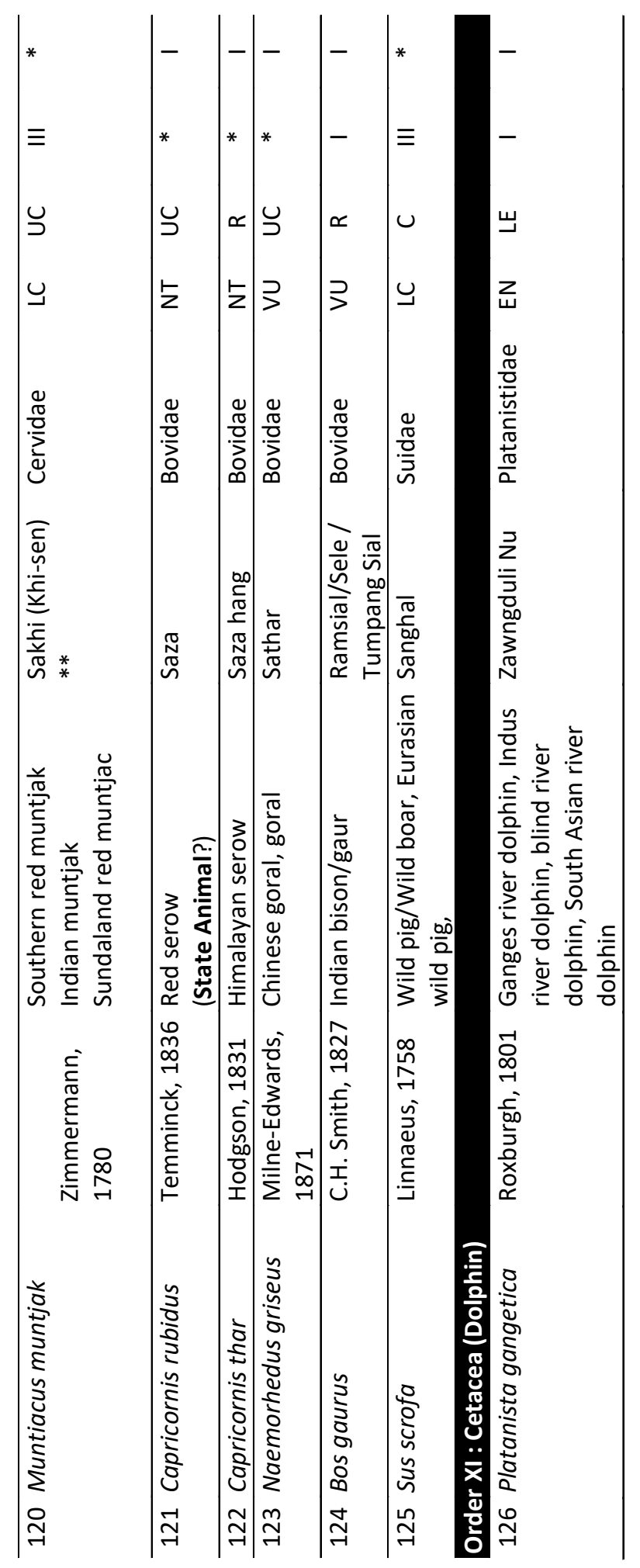




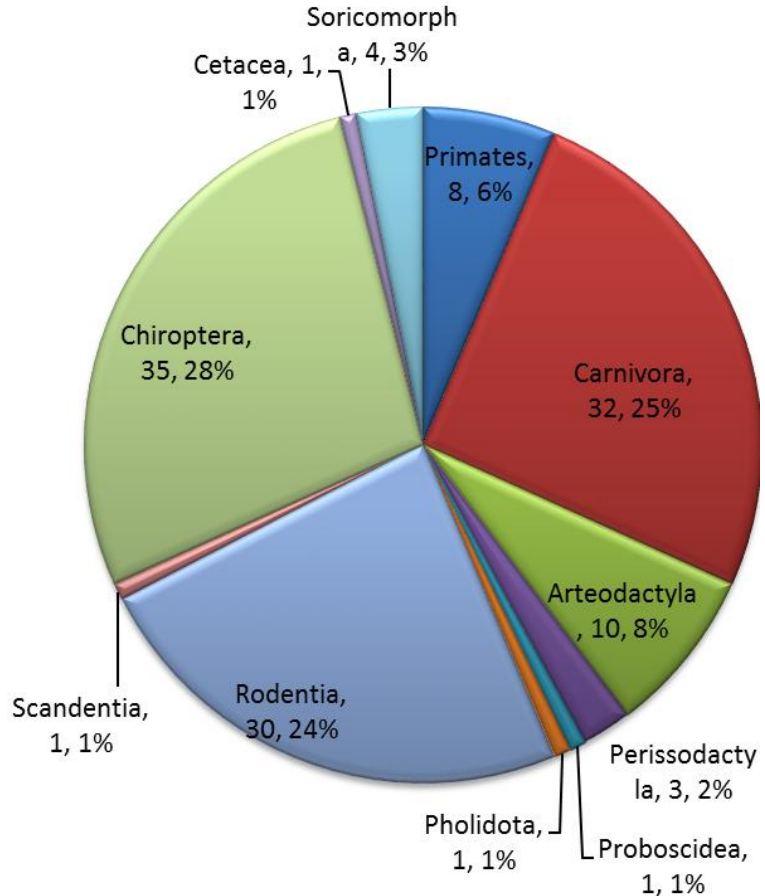

Figure 2 | Order-wise composition of mammals of Mizoram.

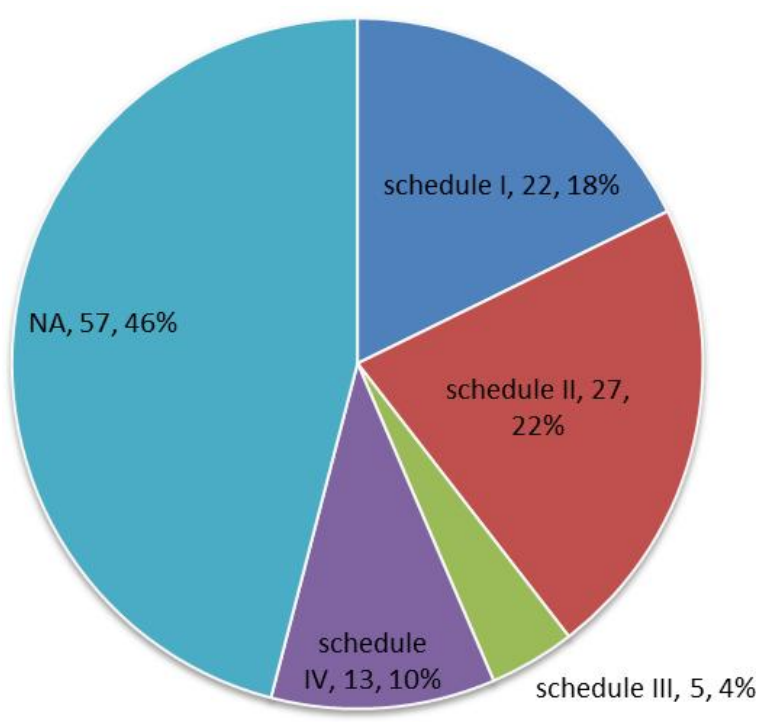

Figure 4 | Mammals of Mizoram under WPA schedule (1972) (NA, not available)

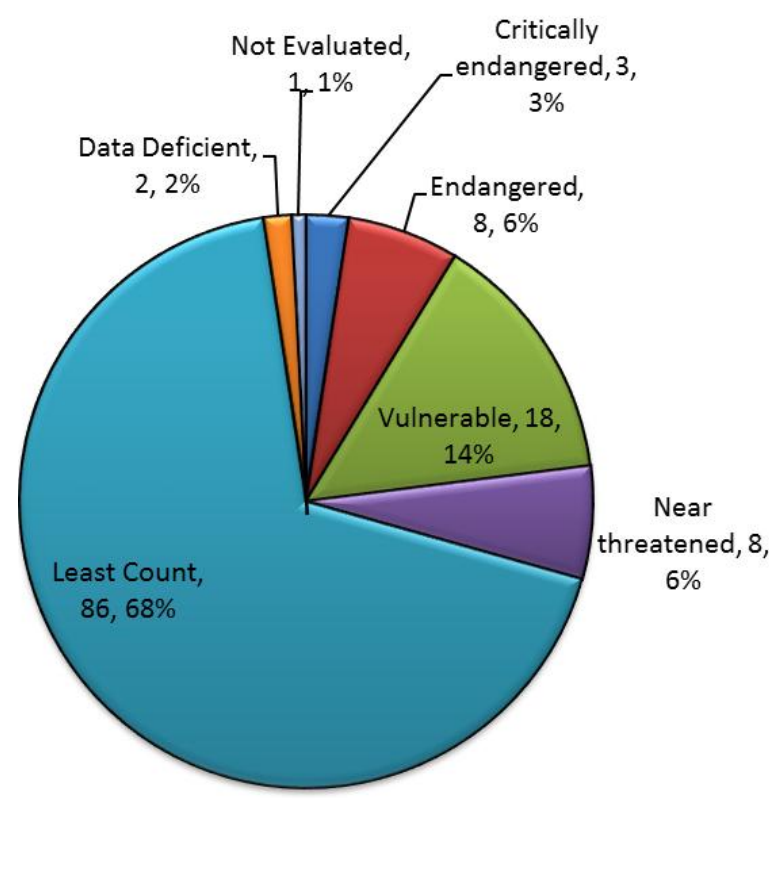

Figure 3 | Mammals of Mizoram under IUCN Threatened category.

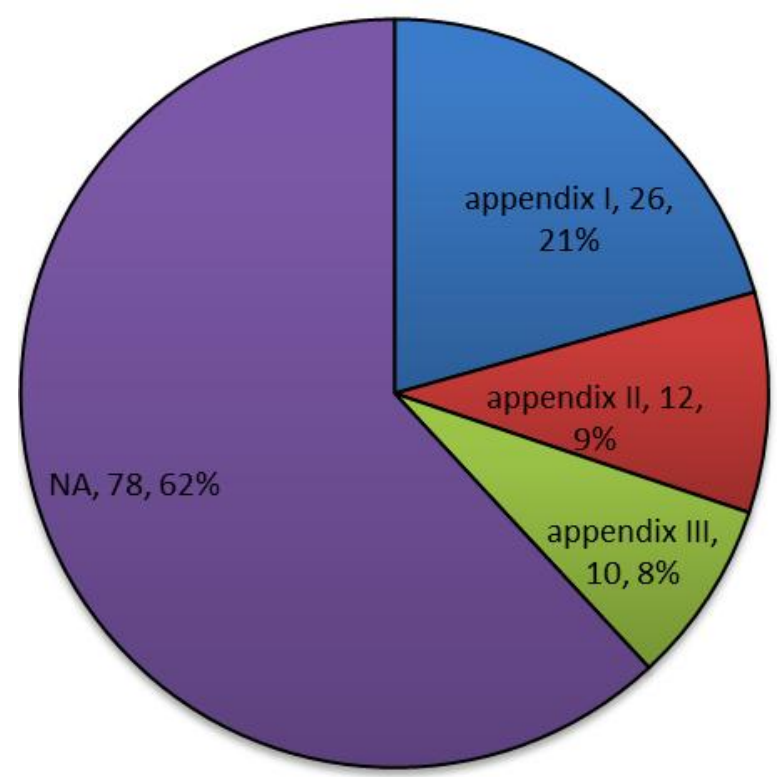

Figure 5 | Mammals of Mizoram under CITES Appendix (NA, not available) 
rised under CITES appendix I. The endangered status of T. phayrei is not aware by the villagers that might perhaps, wipe-off the whole population from the state since poaching is illegally practice in remote areas.

Out of the recorded 126 mammals, 3 species are critically endangered (2\%), out of which two species are categorised as locally extinct; 8 endangered (6\%) including three locally extinct species; 18 vulnerable species (14\%) with one locally extinct species; and 8 near threatened species $(6 \%)$, i.e. a total 37 threatened species are included in the list and the rest 88 species were least concerned, data deficient and not evaluated in the IUCN Red List category ${ }^{27}$ (Figure 3). According to IWPA schedule ${ }^{28} 22$ species belongs to category I $(18 \%), 27$ species in category II $(22 \%), 5$ species in category III (4\%), 13 species in category IV $(10 \%)$ and the status of 57 species, mostly rodents and chiropterans, are not available (46\%) (Figure 4). According to Convention on International Trade in Endangered Species of Wild Fauna and Flora (CITES), 48 species are categorized under different appendices viz. 26 species under appendix I (21\%), 12 species under appendix II (9\%) and 10 species under appendix III $^{29}(8 \%)$ (Figure 5). The local status given in this paper categorised Mizoram mammals as follows - two species of the mammals of Mizoram as abundant, 27 species as common, majority (74 species) are categorised to be uncommon (UC) in the state, 18 species as rare and 5 species are considered to be locally extinct at local (state) level.

Among the reported extinct species Platanista gangetica, Ganges river dolphin (Zawngduli Nu) has been reported from Chhimtuipui (Kolodyne river) (Sawmliana, Pers. comm.) and Tuirial river (Liankima pers. comm.). Rucervus eldii, Eld's deer (sangai) has been recorded in Mizoram by Sawmliana ${ }^{14}$ and Pachuau. ${ }^{26}$ There is a report of two-horned rhinoceros from Mizoram. ${ }^{30}$ Occurrence of rhinoceros was also recorded by Sawmliana, ${ }^{14}$ Pachuau ${ }^{26}$ and Choudhury. ${ }^{31}$ According to Sawmliana ${ }^{14}$ Rhinoceros sondaicus (Javan rhinoceros) became extinct since 1925 and Dicerorhinus sumatrensis (Samutran rhinoceros) extinct since 1935. The latest rhinoceros report dated back to 1947 where it was killed by a hunter in Khawbel village area, Serchhip district (R. Zalinga pers. comm).

There is no record of monotremes and marsupials, only placental mammals are recorded in Mizoram. Axis porcinus hog deer (Sapeng/Tere) is also recorded by Sawmliana ${ }^{14}$ and R. Zalinga and others (pers. comm.), this species is considered to be disappeared from the state, but a recent report indicates its presence in western border of the state (Lalrinmawia, pers. comm.). There are reports that a small sambar-like deer, locally called 'Ria-Nu/Zasuk te chi' is also present ( $\mathrm{H}$. Zahmingthanga \& Lalrinmawia pers. comm). This may be confusion with that of hog deer and/or further confirmation is needed.

The taxonomic position of some species of mammals seems controversial. For instance, Capricornis sumatraensis is recorded as the serow species of Mizoram for a long time and is named as the state animal. However, as per IUCN the distributional ranges are narrow and limited, confining to Indonesia only, a far distant from the present study area. Furthermore, Capricornis thar, the Himalayan serow found in most parts of the Himalayan ranges in India is also recorded from the present investigation. However, the present study revealed that the most common serow in Mizoram is the Capricornis rubidus, red serow, that is commonly called 'Saza' in Mizo, it may represent the serow species of Mizoram as state animal, pending further study on its molecular identification. Moreover, Dey ${ }^{32}$ reported the sighting of red serow $C$. rubidus at Hmuifang, Mizoram. The distributional range of Capricornis rubidus being Assam hills south of Brahmapurta River, ${ }^{32}$ marks the possibility of its occurrence in the neighbouring area, including Mizoram. C. rubidus is the only serow species recorded from the neighbouring Bangladesh. ${ }^{6}$

Similar case has been revealed in giving scientific names to muntjac (barking deer) of Mizoram. This needs careful and thorough scientific study. The present record of barking deer is the Muntiacus muntjak, ${ }^{15,16}$ but the distribution range of this species is far south east-Asia, i.e. Malaysia and Indonesia. However, Mandal et al. ${ }^{24}$ reported a subspecies of $M$. muntjak, i.e. $M$. $m$. 
vaginalis as the barking deer of Mizoram. In contrast, Sawmliana ${ }^{14}$ identified the barking deer of Mizoram as $M$. vaginalis, the northern red muntjak. I strongly agreed with the latter since the morphological appearance of the common barking deer observed in and around Mizoram is more close to $M$. vaginalis and further it is in accordance with the IUCN red list distribution map $^{33}$. The neighbouring state Tripura also records $M$. vaginalis. ${ }^{34}$ During the survey, many sources told me about the presence of two kinds of barking deer in Mizoram which they named them as 'Sakhi' (Khi-sen) and 'Sakhi zâng-hang'. 'The latter have a darker dorsal hairs and bigger in size,' they told ( $\mathrm{H}$. Zahmingthanga, Lalrinmawia \& R. Zalinga pers. comm.). The taxonomic case of muntjak/barking deer is a complicated one as slight variations observed in morphology. Groves ${ }^{35}$ and other authors like Giao et $a .^{36}$ have suggested that northern barking deer, $M$. vaginalis may constitute more than one species. Later, Groves and Grubb ${ }^{37}$ separated the taxon into four species, M. vaginalis ssp. (central range, the most widespread of the four), $M$. malabaricus (extreme southwest of range), $M$. aureus (western range with an outlier in the central part of the range) and $M$. nigripes (eastern parts of the range). Recently, from their molecular analysis results, Martins et al. reported the occurrence of three distinct mitochondrial lineages of red muntjacs in Indian subcontinent viz. Sri Lankan red muntjacs (including the Western Ghats) diverged first from other muntjacs about 1.5 Mya; later northern red muntjacs $M$. vaginalis (including North India and Indochina) and southern red muntjacs M. muntjak (Sundaland) split around $1.12 \mathrm{Mya}^{38}$

Furthermore, a similar circumstance has been seen in case of goral. The existing record of goral of the Mizoram is the Himalayan goral Naemorhedus goral. But recent photographs of the animals appear to be the Chinese goral Naemorhedus griseus, and therefore presented as the goral of Mizoram. This observation was in accordance with the assessment of Duckworth and MacKinnon in the IUCN Red List category, who described the distribution range of $N$. griseus as south of Brahmapurta river in northeast India. ${ }^{39}$
These cases obviously revealed the need of further research on identification and diversity of mammals of Mizoram at species and genetic levels.

Altogether 37 species i.e. 29\% of Mizoram mammals are under IUCN Red list of threatened species; 49 species belongs to IWPA schedule I and II and 38 species falls under CITES appendix I\&II. These data reveals the vulnerability of mammals of Mizoram, they are prone to vanish from the state. It is generally observed that Mizoram in rich in species diversity, but very poor in abundance! Due to various infrastructural development, particularly road and Dam construction and many other anthropogenic activities, including illegal poaching and trade, wildlife resources of Mizoram has been found to dwindle rapidly in recent years. Particularly large mammals are prone to vanishing as they lost their habitats; food, shelter and safety are major concern for these wild mammals in the state. Even the protected sanctuaries are not safe for the wild animals as they were illegally trapped, killed and threatened by various means using traditional traps and modern guns and other tools. Many local inhabitants had feared the animals without considering their roles in the ecosystem and food chains. Despite of the fact that the concern department of the state government and authorities tried their best and some NGO came up to conserve and preserve the precious wildlife; but, obviously environmental and wildlife deterioration continues as in other parts of the world! So, it is the responsibility of every citizen to take wildlife conservation activity in every possible ways.

Owing to its strategic location, Mizoram has a diverse species of mammals inhabiting all parts of the State. However, the status and distribution, rather study of Mizoram mammals is almost left untouched by researchers. This preliminary survey work came up to motivate and challenge young Mizo researchers and any other enthusiasts to face the challenge. The taxonomic dilemma of mammals in Mizoram is an issue since long time back and the sporadic taxonomic status needs to resolve using a thorough and advance technology studies. 


\section{Acknowledgement}

I express my sincere thanks to Dr. C. Vanlalnghaka, Assistant Professor, Department of Zoology, Government Serchhip College, Mizoram and Mr. M. Sawmliana, retired Forester, Chanmari West, Aizawl for rendering their immense help in technical component of the paper. Thanks to all those officers and staff of Environment and Forest department, all eminent citizens, hunters, village heads and teachers all over Mizoram for sharing their valuable experience and knowledge. I am grateful to Dr. Lalramliana, Department of Zoology, Pachhunga University College for critical review and suggestions.

\section{References}

I. Wilson, D.E. \& Reeder, D.M. (2005). Mammal Species of the World: A Taxonomic and Geographic Reference. 3rd Edition, Vol. I E 2. The Johns Hopkins University Press, Baltimore, i-xxxv+I-743pp \& pp.i-xvii+745-2I42.

2. Sharma, G., Kamalakannan, M. and Venkataraman, K. (2013). A Checklist of Mammals of India with their distribution and conservation status. ZSI e-publication. Published by the Director, Zool. Surv. India, Kolkata700 053, India. I2I pp.

3. Menon, V. (2009). Field Guide to Indian Mammals. Christopher Helm, A\&C Black Publishers Ltd. Lodon. Pp. I-20o.

4. Zoos' Print. Checklist of Indian Mammals Revised and Updated 2008. XXIII(8) August 2008, (RNI 9:II).

5. h t t p s : / / e n.wiki pedia.org / w i ki / List_of_mammals_of_Myanmar\#cite_note-I accessed on $2 \mathrm{I}^{\text {st }}$ March 2017

6. IUCN Bangladesh (2015). Red List of Bangladesh Volume 2: Mammals. IUCN, International Union for Conservation of Nature, Bangladesh Country Office, Dhaka, Bangladesh, pp. xvi+232.

7. Nameer, P.O. (2015). A checklist of mammals of Kerala, India. Journal of Threatened Taxa 7(13), 7971-7982; http://dx.doi.org/Io.II609/ jott.2000.7.13.7971-7982

8. Choudhury, A. (1997). Checklist of the Mammals of Assam. Gibbon Books and Assam Science Technology and Environment Council, Guwahati. I03p.

9. Meghalaya Biodiversity Board. 139 sp under 83 genera that belongs to 27 families in Meghalaya http:// megbiodiversity.nic.in/faunal-biodiversity.html accessed on 2017-03-2I

Io. Envis centre, Manipur. List of mammals. http:// manenvis.nic.in/Database/Mammals_2908.aspx accessed on 24.3.2017

II. Tripura Biodiversity Board. The latest estimate by them put the number of land mammal species at 90 , from 65 genera and Io Orders (Gupta, 200o). http:// biodiversity.tripura.gov.in/Fauna accessed on 21.3.2017

12. Envis Centre, Nagaland. Fauna. http:// www.nagenvis.nic.in/Database/fauna_852.aspx accessed on 24.3.2017

13. De, J.K., Mandal, A.K. and Ghosh, M.K. (2006). Mammals In. Director Ed. Fauna of Arunachal Pradesh, State Fauna Series, I3(Part-l) Published by the Director, Zool Surv. India, Kolkata. Pp. I-396.

I4. Sawmliana, M. (2013). The Book of Mizoram Plants. $2^{\text {nd }}$ edn. P. Zakhuma, Aizawl, pp. 447-463.

I5. Mizo ENVIS Newsletter. Mizoram State Pollution Control Board (MPCB). Volume 3, No. I, Pages 3-5.

16. Zonunmawia, A.C. and Pradhan, N. (2004). Mizoram and its Wildlife (Checklist of mammal, amphibian, reptile, bird, fish, invertebrate faunal and flora). Centre for Environment Protection, Aizawl. Pp. I-69.

17. Lalmuansanga, K. (2009). Nungchate Chanchin Volume r. K. Bawlliana, Aizawl. Pp. I-9o.

I8. Mandal, A.K, Poddar, A.K. and Bhattacharyya, T.P. (1997). Some New Records of Bats from Mizoram, India, Record of Zoological Survey of India, 96 ( I - 4), 7 I3.

19. Mandal, A.K, Poddar, A.K. and Bhattacharyya, T.P. (2000a). Further New Records of Bats from Mizoram, India. Record of Zoological Survey of India, 98(Part-2), I47-I54.

20. Zirliana, K. (2009). Brief Record on Mizoram Mautam, 2007-2008 (A compiled Information and Datas, Directorate of Agriculture (CH), Govt. of Mizoram, Aizawl. p. 5

2I. Mandal, A.K, Poddar, A.K. and Bhattacharyya, T.P. (200ob). Some New Records of Rodents from Mizoram, India. Record of Zoological Survey of India, 
98(Part-1), I3I-I35.

22. Vanlalnghaka (2013). Study on bat diversity in and around Lengteng Wildlife Sanctuary, Mizoram, India. Science Vision $\mathbf{1 3}(2), 70-75$.

23. Vanlalnghaka (2014). Nectar-feeding bat, Cynopterus sphinx pollinate Parkiaspeciosa flowers and increase fruit production. Sci Vis, I4(2), 67-73.

24. Mandal, A.K., Poodar, A.K. and Bhattacharya, T.P. (2007). Mammals In: Fauna of Mizoram. Zoological Survey of India, State Fauna Series I4 (Eds. Director, ZSI, Kolkata). pp 6o9-653.

25. Zothansiama and Solanki, G.S. (20II). Male-male sexual behaviour in adult captive stump-tailed macaque, Macaca arctiodes. Science Vision II(I), 3I-39.

26. Pachuau, R. (2009). Mizoram - A study in Comprehensive Geography. Northern Book Centre, New Delhi. pp.94-95

27. IUCN. 2017. IUCN Red List of Threatened Species. Version 2016.3. International Union for Conservation of Nature. Accessed at http://www.iucnredlist.org, I2 April 2017.

28. IW(P)A Schedule. Scheduled Species of mammals Indian Wildlife (Protection) Act, 1972. Schedule I http:// envfor.nic.in/legis/wildlife/wildlife2sı.pdf; Schedule II http://envfor.nic.in/legis/wildlife/wildlifess2.pdf; Schedule 3 http://vindhyabachaoorg/ wildlife_guidelines/schedule_species_mammals.pdf and Schedule IV http://www.moef.nic.in/legis/wildlife/ wildlife2s4.html

29. CITES. 2017. Convention on International Trade in Endangered Species of Wild Fauna and Flora. Appendices I, II and III. Accessed at http://www.cites.org, I3 April 2017.

30. Chatterjee, S. (1995). Mizo Chiefs and the Chiefdom, MD Publications Pvt. Ltd. New Delhi) p.55.

31. Choudhury, A. (1997). The status of the Sumatran rhinoceros in north-eastern India. Oryx, 3I (2), I5I-I52.
32. Dey, A. (2016). Red Serow at Hmuifang, Mizoram. Conservation India http://www.conservationindia.org/ gallery/red-serow-hmuifang-mizoram Accessed on 2.3.2017

33. IUCN (International Union for Conservation of $\mathrm{Na}$ ture) 2016. Muntiacis vaginalis. The IUCN Red List of Threatened Species. Version 2016-3. http:// maps.iucnredlist.org/map.html $\mathrm{id}=\mathrm{I} 3655 \mathrm{I}$

34. Agarwal, V.C. \& Bhattacharya, T.P. (1977). Report on a collection of mammals from Tripura. Record of Zoological Survey of India, 73, 135-157.

35. Groves, C. (2003). Taxonomy of ungulates of the Indian subcontinent. Bombay Natural History Society. 10o, 34I -6I. Available from: http://hdl.handle.net/I885/76I87.

36. Giao, P.M, Touc, D., Dung, V.V., Wikramanayake, E.D., Amato, R., Arctander, P. and MacKinnon, J.R. (1998). Description of Muntiacus truongsonensis, a new species of muntjac (Artiodactyla: Muntiacidae) from Central Vietnam, and implications for conservation. Animal Conservation. I, 6I-68.

37. Groves, C. and Grubb, P. (20II). Ungulate Taxonomy, Johns Hopkins University Press, Baltimore, Maryland, 317. pp. ISBN-I3 978-I-42I4-0093-8 and ISBN-IO I-42I4o.93-6

38. Martins, R.F., Fickel, J., Le, M., van Nguyen, T., Nguyen, H.M., Timmins, R., Gan, H.M., Rovie-Ryan, J.J., Lenz, D., Förster, D.W. and Wilting, A. (2017). Phylogeography of red muntjacs reveals three distinct mitochondrial lineages. BMC Evolutionary Biology, 17:34. DOI: I0.II86/sI2862-0I7-0888-o

39. Duckworth, J.W. \& MacKinnon, J. (2008). Naemorhedus goral. The IUCN Red List of Threatened Species 2008:e.TI4296A4430073. http://

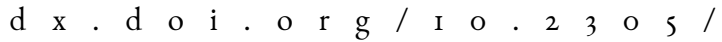
IUCN.UK.2008.RLTS.TI4296A4430073.en. Downloa ded on 23 May 2017. 